\title{
Hyperoxygenation Ameliorates Stress-induced Neuronal and Behavioral Deficits
}

\author{
Juli Choi ${ }^{1}$, Hye-Jin Kwon ${ }^{1}$, Ju-Young Seoh ${ }^{2,3}$ and Pyung-Lim Han ${ }^{1 *}$ \\ ${ }^{1}$ Department of Brain and Cognitive Sciences, Ewha Womans University, Seoul 03760, ${ }^{2}$ Department of Microbiology, College \\ of Medicine, Ewha Womans University, Seoul 07985, ${ }^{3}$ Central Research Laboratory, GI Biome, Inc., Seongnam 13201, Korea
}

\begin{abstract}
Hyperoxygenation therapy remediates neuronal injury and improves cognitive function in various animal models. In the present study, the optimal conditions for hyperoxygenation treatment of stress-induced maladaptive changes were investigated. Mice exposed to chronic restraint stress (CRST) produce persistent adaptive changes in genomic responses and exhibit depressive-like behaviors. Hyperoxygenation treatment with $100 \%$ $\mathrm{O}_{2}\left(\mathrm{HO}_{2}\right)$ at 2.0 atmospheres absolute (ATA) for $1 \mathrm{~h}$ daily for 14 days in CRST mice produces an antidepressive effect similar to that of the antidepressant imipramine. In contrast, $\mathrm{HO}_{2}$ treatment at 2.0 ATA for $1 \mathrm{~h}$ daily for shorter duration $\left(3,5\right.$, or 7 days), $\mathrm{HO}_{2}$ treatment at 1.5 ATA for 1 $\mathrm{h}$ daily for 14 days, or hyperbaric air treatment at 2.0 ATA $\left(42 \% \mathrm{O}_{2}\right)$ for $1 \mathrm{~h}$ daily for 14 days is ineffective or less effective, indicating that repeated sufficient hyperoxygenation conditions are required to reverse stress-induced maladaptive changes. $\mathrm{HO}_{2}$ treatment at 2.0 ATA for 14 days restores stress-induced reductions in levels of mitochondrial copy number, stress-induced attenuation of synaptophysin-stained density of axon terminals and MAP-2-staining dendritic processes of pyramidal neurons in the hippocampus, and stress-induced reduced hippocampal neurogenesis. These results suggest that $\mathrm{HO}_{2}$ treatment at 2.0 ATA for 14 days is effective to ameliorate stress-induced neuronal and behavioral deficits.
\end{abstract}

Key words: Hyperoxygenation, Chronic stress, Mitochondria, Neurogenesis

\section{INTRODUCTION}

Physiological stress activates the hypothalamus-pituitary glandadrenal cortex, resulting in glucocorticoid release into the circulatory system [1-3]. Glucocorticoids normally enhance and maintain metabolic and physiological homeostasis to effectively cope with internal and environmental changes $[4,5]$. However, with stress overload, chronically released glucocorticoids produce maladaptive changes in the brain, resulting in behavioral impairment and reduced responsiveness to new stress $[1,6]$.

Rodent models have been used to understand the neural and molecular mechanisms underlying stress-induced adaptive

Submitted August 15,2021, Revised December 22, 2021,

Accepted December 23, 2021

* To whom correspondence should be addressed.

TEL: 82-2-3277-4130, FAX: 82-2-3277-3419

e-mail: plhan@ewha.ac.kr changes in the brain [7-9]. Chronic stress causes oxidative stress and mitochondrial dysfunction in the brain [10-12] and produces structural atrophy of pyramidal neurons in the hippocampus [13-15] as well as, suppression of hippocampal neurogenesis [16-18]. Chronic stress reduces the expression of brain-derived neurotrophic factor (BDNF) in the hippocampus [19, 20]. Conversely, transgenic overexpression of BDNF in the hippocampus suppresses stress-induced reduction of dendritic branching in the CA3 hippocampus and produces antidepressive effects [21]. Maladaptive changes caused by chronic stress result in changes in the neural activity of various neural networks regulating emotional behaviors [22]. Thus, chronic stress encompasses the genomic responses of key factors regulating neural circuits, thereby producing altered behavioral outputs including depressive behaviors.

Hyperoxygenation with $100 \% \mathrm{O}_{2}\left(\mathrm{HO}_{2}\right)$ treatment at $2 \sim 3$ atmospheres absolute (ATA) produces neuroprotective effects in animal models with traumatic brain injury $[23,24]$ and ischemic brain injury $[25,26]$ and enhances hippocampal neurogenesis [27,
Copyright (c) Experimental Neurobiology 2021. www.enjournal.org
This is an Open Access article distributed under the terms of the Creative Commons Attribution Non-Commercial License (http://creativecommons.org/licenses/by-nc/4.0) which permits unrestricted non-commercial use, distribution, and reproduction in any medium, provided the original work is properly cited. 
28]. Hyperoxygenation treatment increases the expression of neurotrophic factors, such as BDNF, neurotrophin 3 (NT-3), and NT$4 / 5[29,30]$, enhances the expression of hypoxia-inducible factors (HIFs) and HIF-directed signaling events [30-32], and increases the expression of MeCP2, matrix metalloproteinase-2 (MMP-2), MMP-9, and tissue plasminogen activator (tPA) in the hippocampus of a transgenic mouse model (Tg-APP/PS1) of Alzheimer disease (AD) [33]. Hyperoxygenation treatment increases mitochondrial function and glycolytic energy metabolism [34]. Furthermore, hyperoxygenation treatment improves neuritic atrophy of hippocampal neurons and cognitive deficits in Tg-APP/PS1 mice, and these changes are associated with increased expression of $\mathrm{BDNF}$ and TrkB receptor activation in the hippocampus [30, 33]. These results indicate that hyperoxygenation can be used to treat neuronal and behavioral deficits produced by chronic stress. However, certain safety and effectiveness concerns have not been carefully investigated in the brain of animal models of depression.

In the present study, the optimized conditions for hyperoxygenation treatment that stably remedy stress-induced maladaptive changes were investigated.

\section{MATERIALS AND METHODS}

\section{Animals}

Male C57BL/6J mice (7-week-old) were purchased from Daehan BioLink, Inc. (Eumsung, Chungbuk, Korea). Ncfl (p47phox) knockout mice [35] were obtained from the Jackson Laboratory and were backcrossed to $\mathrm{C} 57 \mathrm{BL} / 6 \mathrm{~J}$ as previously described [36]. Genotyping of Ncf1 KO mice was performed using genomic PCR with the following primer set: 5'-TGGAAGAAGCTGAGAGTTGAGG-3' and 5'-TCCAGGAGCTTATGAATGACC-3'. The PCR products were digested with MspI; the $160 \mathrm{bp}$ fragment was obtained for wild-type and the 102 and 58 bp fragments were obtained for homozygotes.

Mice were housed in pairs in standard clear plastic cages filled with wood shavings (TAPVEI, Paekna, Estonia) in a controlled temperature $\left(23^{\circ} \mathrm{C}\right)$ - and humidity (50 60\%) environment under 12-h light/dark cycle conditions (from 7:00 a.m. to 7:00 p.m.), and were allowed free access to food in the cages. Mice were handled in accordance with the animal care guidelines of Ewha Womans University and restraint treatment procedures in this study were approved by the Ewha Womans University Animal Care and Use Committee (IACUC 19-016).

\section{Restraints and imipramine treatment}

Mice were restrained as previously described $[36,37]$. To implement restraint, mice were placed in a $50-\mathrm{ml}$ polypropylene tube with numerous punched holes for ventilation and restrained for $2 \mathrm{~h}$ daily for indicated days. Control mice housed in pairs were maintained in home cages. Imipramine (I0899, Sigma-Aldrich, St. Louis, MO, USA) was intraperitoneally injected at a dose of $20 \mathrm{mg} /$ $\mathrm{kg} /$ day in a volume of $100 \mu \mathrm{L}$ for the indicated days.

\section{Hyperbaric oxygenation treatment}

Mice were treated with hyperoxygenation using a hyperbaric chamber (Particla Ltd., Daejeon, South Korea) as previously described $[30,33,38]$. Mice housed in a clear plastic mini-cage $(18 \times 12 \times 14 \mathrm{~cm})(2$ or 3 animals per cage $)$ were placed in the hyperbaric chamber and exposed to $100 \% \mathrm{O}_{2}$ daily for $60 \mathrm{~min}$ at 2.0 ATA for the indicated number of days. The desired compressed pressure in the chamber was achieved by supplying the chamber with $100 \% \mathrm{O}_{2}$ at $5.0 \mathrm{~L} / \mathrm{min}$ at 2.0 ATA for $12 \mathrm{~min}$, followed by continual replenishment with $100 \% \mathrm{O}_{2}$ at $1.0 \mathrm{~L} / \mathrm{min}$ for $60 \mathrm{~min}$. Decompression was performed at a rate of $1.5 \mathrm{~L} / \mathrm{min}$ for over 40 min. During the hyperoxygenation treatment, oxygen level and temperature changes inside the chamber were monitored. Hyperoxygenation treatment was initiated at 10:00 a.m.

Hyperbaric atmospheric air treatment was performed as previously described [30]. Mice were treated as described above but with atmospheric air instead of $100 \% \mathrm{O}_{2}$ at 2.0 ATA; therefore, mice were exposed to $42 \% \mathrm{O}_{2}$ at 2.0 ATA daily for $60 \mathrm{~min}$ for the indicated number of days.

\section{Measurement of mitochondrial DNA copy number and mitochondrial biogenesis}

Quantitative real-time PCR analysis of mitochondrial DNA (mtDNA) copy number and mitochondrial biogenesis factors were carried out as previously described $[30,33,39]$ with minor modifications. Briefly, total RNA was isolated from hippocampal tissue homogenates using the TRIzol reagent (15596-018, Invitrogen). Two $\mu \mathrm{g}$ of total RNA were treated with DNAse I and then converted into complementary DNA (cDNA) using a reverse transcriptase system (Promega, Madison, WI, USA). Real-time PCR was performed using the SYBR Green Supermix system (Bio-Rad Laboratories, Foster City, CA) and the CFX 96 Real-Time PCR System Detector (Bio-Rad Laboratories). The detected signals were normalized against the quantity of Gapdh.

For quantification of mitochondrial biogenesis factors, following primer sets were used: Sirt1, forward 5'-GATCCTTCAGTGTCATGGTTC-3' and reverse 5'-ATGGCAAGTGGCTCATCA-3'; PGC-1 $\alpha$, forward AAACTTGCTAGCGGTCCTCA-3' and reverse 5'-AAACTTGCTAGCGGTCCTCA-3'; Nrf1, forward 5'-GTGCTGATGAAGACTCCCCT-3' and reverse 5' - AAACACATGAGGCCGTTTCC-3'; Nrf2, forward 5'- 
and 5'- GAGGTCACCACAACACGAAC-3' and reverse 5' -TCACTTCATCCACCCAGAGC-3'; Tfam, forward 5' and 5'- GCATCCCCTCGTCTATCAGT-3' and reverse 5' -CACAGGGCTGCAATTTTCCT-3'; Nqo 1, forward 5'-TGAAGGAGGCTGCTGTAGAG-3' and 5'-GTTCGGCCACAATATCTGGG-3'; and GAPDH, forward 5'-AGAAGGTGGTGAAGCAGGCATC-3' and reverse 5'-CGAAGGTGGAAGAGTGGGAGTTG-3'

Mitochondrial DNA isolation was isolated using Mitochondrial DNA Isolation Kit (ab65321; Abcam, Cambridge, MA, USA), according to the manufacturer's instructions. Tissue homogenate in cytosol extraction buffer was centrifuged at $600 \times \mathrm{g}$ for $10 \mathrm{~min}$ at $4^{\circ} \mathrm{C}$ to pellet nuclei and intact cells. The supernatant was collected and centrifuged at $11,000 \times \mathrm{g}$ at $4^{\circ} \mathrm{C}$ for $30 \mathrm{~min}$. After removing supernatant, the pellet containing mitochondria was resuspended in mitochondrial lysis buffer and incubated for $10 \mathrm{~min}$, then added with enzyme mix and incubated at $50^{\circ} \mathrm{C}$ for $60 \mathrm{~min}$. After treating with $100 \%$ ethanol and kept on ice for $10 \mathrm{~min}$, the reaction was centrifuged for $5 \mathrm{~min}$ and the mtDNA was harvested from the reaction. Isolated mtDNA was resuspended in TE and was quantified.

For quantification of mtDNA copy number, following primer sets were used: mt-Nd1, forward 5'-CACTCCTCGTCCCCATTCTA-3' and reverse 5'-ATGCCGTATGGACCAACAAT-3'; mt-Nd3, forward 5'-TAGTTGCATTCTGACTCCCCCA-3' and 5'-GAGAATGGTAGACGTGCAGAGC-3'; mt-Nd4, forward 5'-ATTATTATTACCCGATGAGGGAACC-3' and reverse 5' - ATTAAGATGAGGGCAATTAGCAGT-3'; mtNd5, forward 5'-TCCTACTGGTCCGATTCCAC-3' and 5' -TGATGTCGTTTTGGGTGAGA-3'; mt-Cyb, forward 5' -CCCAGCTACTACCATCATTCAAGT-3' and reverse 5'-GATGGTTTGGGAGATTGGTTGATGT-3'; mt-Cox1, forward 5'-CTGAGCGGGAATAGTGGGTA-3' and reverse 5' -TCAGTTTCCAAAGCCTCCA-3'; mt-Atp6, forward 5'-AATTACAGGCTTCCGACACAAAC-3' and reverse 5'-TGGAATTAGAATTGGAGTTCCT-3'; and mt-Dloop, forward 5-AATCTACCATCCGTGAAACCC-3' and reverse 5'-GCCCGGAGCGAGAAGAG-3'.

\section{Immunohistochemistry}

Immunohistochemical analysis was performed as previously described $[30,37]$. Mice were perfused with $0.9 \%$ saline via a transcardiac method, followed by perfusion with $4 \%$ paraformaldehyde in $0.1 \mathrm{M}$ phosphate buffer, $\mathrm{pH}$ 7.4. Brains were removed and then fixed further in $4 \%$ paraformaldehyde at $4{ }^{\circ} \mathrm{C}$ overnight. Brains were sliced using a vibratome (Leica VT 1000S; Leica Instruments, Nussloch, Germany) into 40- $\mu$ m-thick sections. Brain sections were incubated in 3\% hydrogen peroxide in 1 X PBS for $30 \mathrm{~min}$ at room temperature (RT) to block endogenous peroxidase activity and washed three times with PBST. Non-specific binding was blocked with 5\% BSA for $1 \mathrm{~h}$ at RT, and samples were incubated with primary antibody in $5 \%$ BSA solution at $4{ }^{\circ} \mathrm{C}$ overnight. For immunohistochemistry, biotinylated goat anti-mouse IgG (BA9200, Vector Laboratories) or biotinylated horse anti-goat IgG (BA-9500, Vector Laboratories, Burlingame, CA, USA) were used. After washing, stained signals were visualized using an ABC Elite kit (PK 6200, Vector Laboratories) and 3,3'-diaminobenzidine (D5637, Sigma-Aldrich) in 0.1 M Tris- $\mathrm{HCl}$ (pH 7.4). For immunofluorescent staining, a secondary antibody labeled with DyLight488 anti-mouse (DI-2594, Vector Laboratories) diluted at 1:500 in $1 \mathrm{X}$ PBST was used. Stained sections were mounted on a gelatin-coated slide glass with fluorescent mounting medium (DAKO) or DAPI staining mounting solution (H-1200, Vector Laboratories).

For the quantification of MAP-2-stained dendritic density in the stratum radiatum (SR), the relative intensity of MAP-2 fluorescence levels in the SR over the relative intensity of MAP-2 fluorescence levels in the CA1 pyramidal cell layer was measured and presented as a ratio of the control. For the quantification of synaptophysin-stained stained densities of axon terminals in the SR, the relative intensity of synaptophysin fluorescence levels in the SR was measured and presented as a ratio of the control. For the quantification of the thickness of the CA1 and CA3 pyramidal cell layer, the thickness of anti-NeuN-stained CA1 and CA3 pyramidal cell layer was measured and presented as a ratio relative to the control. Stained sections were analyzed using an Olympus BX 51 microscope equipped with a DP71 camera. Stained images were analyzed using MetaMorph Microscopy Automation \& Image Analysis software (Molecular Devices Co., San Jose, CA, USA). The following primary antibodies used: anti-MAP2 (05-346; Millipore, Burlington, MA, USA, 1:1,000; RRID: AB_309685), anti-NeuN (MAB377, Millipore), anti-synaptophysin (MAB368, Millipore, 1:1,000), and anti-VDAC (\# PA1-954A, Thermo Fisher Scientific).

\section{Behavioral tests}

The behavioral tests were performed as previously described $[37,40]$. Mice were brought to the behavior testing room $30 \mathrm{~min}$ before the start of each behavioral test. The behavior testing room was illuminated by indirect light of 20 lux for the sociability test and 250 lux for the tail suspension test and forced swim test. The background sound in the testing room was masked with $65 \mathrm{~dB}$ of white noise using a white noise generator (HDT Korea, Seoul, Korea). After each behavioral test, the parts of the apparatus exposed 
to mice were frequently cleaned with $70 \%$ ethanol. All behavioral tests were performed during the light cycle phase (9 a.m. 3 p.m.).

\section{Sociability test}

The sociability test was carried out in the two-choice field as previously described $[37,40]$. Briefly, the U-shaped two-choice field was prepared by partitioning an open field $(40 \mathrm{~cm} \times 40 \mathrm{~cm})$ with a wall (20-cm wide and 20-cm high), thereby the open field was partially divided into two identical fields. A circular grid cage (12 $\mathrm{cm}$ in diameter $\times 33 \mathrm{~cm}$ in height) was presented on each side of the U-shaped two-choice field. For habituation to the field, a subject mouse was allowed to freely explore the U-shaped two-choice field with empty circular grid cages on each side for $5 \mathrm{~min}$ and returned to their home cage. After $10 \mathrm{~min}$, a social target mouse was placed in a circular grid cage at one side and the subject mouse was placed in the center of the U-shaped two-choice field where the subject mouse was able to see both grid cages. The subject mouse was allowed to explore both fields for $10 \mathrm{~min}$ while recording the trajectory spent in the fields using a video tracking system (SMART, Panlab S.I., Barcelona, Spain) The field with a circular grid cage containing the social target and the field with an empty circular grid cage were defined as the target field and non-target field, respectively. Social target mice were the same age and sex as the subject mice and had never been exposed to subject mice from the acclimation stage. Social target mice were used $3 \sim 4$ times as a social target. All behavioral tests were recorded with a computerized video tracking system (SMART; Panlab S.I.).

\section{Tail suspension test}

The tail suspension test (TST) was performed as previously described $[37,40]$. Mice were suspended $50 \mathrm{~cm}$ above the bottom floor individually by fixing their tails with adhesive tape to the ceiling of a shelve $(50 \mathrm{~cm} \times 25 \mathrm{~cm} \times 35 \mathrm{~cm})$. The subject mouse was suspended for $6 \mathrm{~min}$ and the cumulative immobility time measured. Behavioral performances were recorded using a webcam recording system (HD Webcam C210, Logitech, Newark, CA, USA) and subsequently analyzed.

\section{Forced swim test}

The forced swim test (FST) was performed as previously described $[37,40]$. Mice were placed for $6 \mathrm{~min}$ in a Plexiglas cylinder (15 cm in diameter $\times 27 \mathrm{~cm}$ in height) containing water at $24^{\circ} \mathrm{C}$ with a depth of $15 \mathrm{~cm}$, and the cumulative immobility time was measured for the final $5 \mathrm{~min}$. Immobility was defined as the time when a mouse was floating with all limbs motionless. The performance during the test was recorded using a webcam recording system (HD Webcam \#C210; Logitech) and then analyzed.

\section{Statistical analysis}

A two-sample comparison was conducted using Student's t-test, and multiple comparisons performed using one-way ANOVA followed by the Newman-Keuls post hoc test or two-way ANOVA followed by Bonferroni post hoc test. All data are presented as mean \pm standard error of the mean (SEM), and statistical significance was accepted at the $5 \%$ level.

\section{RESULTS}

\section{Repeated and hyperbaric hyperoxygenation treatment was required to produce antidepressive effects}

Mice restrained for 2-h daily for 14 days (chronic restraint stress, CRST) exhibit depressive-like behaviors that last for more than 3 months $[11,41]$. In the present study, we examined the time course effects of hyperoxygenation treatment on stress-induced depressive-like behaviors. Mice subjected to CRST were treated with $100 \% \mathrm{O}_{2}$ at 2.0 ATA for $1 \mathrm{~h}$ daily for 3, 7, or 14 days from poststress day 1 , and then were placed in the behavioral tests during the post-stress days 15 to 21 (Fig. 1A). The 7-day and 14-day $\mathrm{HO}_{2}$ regimens, but not the 3-day $\mathrm{HO}_{2}$ regimen, reversed stress-induced reduction in social interaction in the sociability test (Fig. 1A C). In the tail suspension test (TST), the 3-day, 7-day and 14-day duration $\mathrm{HO}_{2}$ regimens all suppressed stress-induced increased immobility (Fig. 1D). However, in the forced swim test (FST), the 14-day $\mathrm{HO}_{2}$ regimen, but not the 3-day and 7-day regimens, suppressed stress-induced increased immobility (Fig. 1E). These results indicate that the 3 -day or 7-day duration regimen produces antidepressive effects only in the selective behavioral tests, and the 14-day duration regimen restores a full spectrum of stress-induced behavioral deficits.

Next, how $\mathrm{HO}_{2}$ treatment affects body weight gain was examined. Mice repeatedly restrained for 2 -h showed reduced body weight during the first 4 days and thereafter their body weight progressively increased over days, but restraint-exposed mice had lower body weights than the control until the end of the 14-day stress phase. During the post-stress period, the body weights of CRST mice had remained lower than the control (Fig. 2A, B). Poststress treatment with the 14-day 2.0-ATA $\mathrm{HO}_{2}$ regimen and treatment with the antidepressant imipramine (IMI) in CRST mice did not change the body weight gain (Fig. 2A, B). The 14-day 2.0-ATA $\mathrm{HO}_{2}$ regimen reversed stress-induced reduced social interaction in the sociability test and stress-induced increased immobility in the TST and FST, and hyperoxygenation-induced changes were comparable to IMI effects. Thus, the 14-day $\mathrm{HO}_{2}$ regimen produces antidepressive effects as similar as those by IMI (Fig. 2C E).

Next, we investigated whether the 2.0-ATA hyperbaric condition 


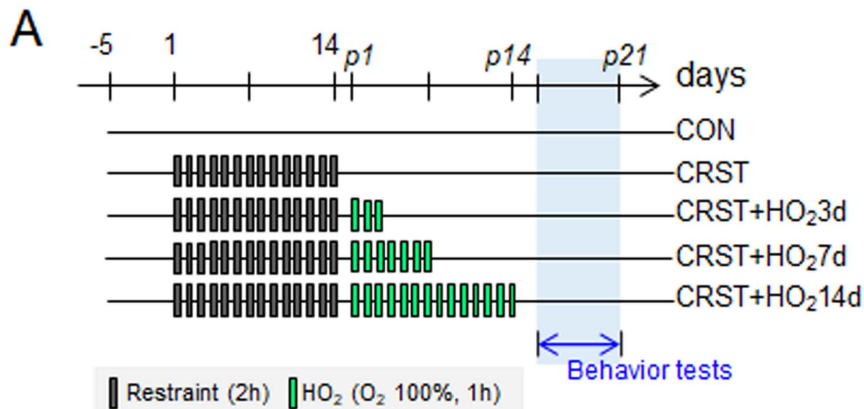

B
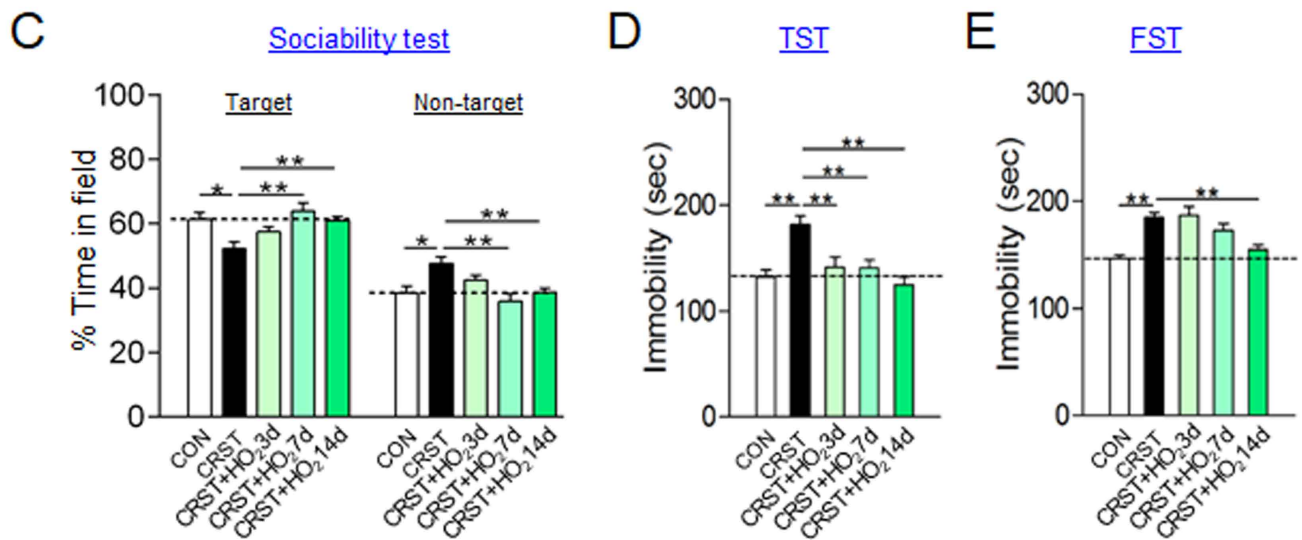

Fig. 1. Repeated hyperoxygenation treatment was required to produce antidepressive effects in CRST mice. (A) Experimental design. CRST mice were treated with $100 \% \mathrm{O}_{2}\left(\mathrm{HO}_{2}\right)$ at 2 ATA for $1 \mathrm{~h}$ daily for 3, 7, or 14 days. CON (13), naïve control; $\mathrm{CRST}(16)$, $\mathrm{CRST}+\mathrm{HO}_{2} 3 \mathrm{~d}(6), \mathrm{CRST}+\mathrm{HO} \mathrm{H}_{2} 7 \mathrm{~d}(15)$, and CRST $+\mathrm{HO}_{2} 14 \mathrm{~d}(15)$, CRST mice and CRST mice treated with $\mathrm{HO}_{2}$ for 3, 7, or 14 days. (n), number of animals for the indicated groups. The results of two independent sets of experiments were combined. (B, C) The percent time of social interaction in the two-choice field (B) of the sociability test (C) of the indicated groups. The fields with the social target and the non-target are indicated (B). (D, E) The immobility time in the TST (D) and FST (E) of the indicated groups. Mean \pm SEM. ${ }^{* * *}$ difference between indicated group. ${ }^{*} \mathrm{p}<0.05,{ }^{* *} \mathrm{p}<0.01$ (one-way ANOVA and Newman-Keuls post hoc test).

can be replaced with the 1.5-ATA hyperbaric condition. The 14day 2.0- $\mathrm{ATA} \mathrm{HO}_{2}$ regimen in CRST mice reversed stress-induced increased immobility in the FST and TST after 3 5 days of $\mathrm{HO}_{2}$ treatment and also after 17 19 days of $\mathrm{HO}_{2}$ treatment (Fig. 2F J). Similar 14-day 1.5-ATA $\mathrm{HO}_{2}$ treatment in CRST mice reversed stress-induced increased immobility in the FST and TST after 3 5 days of $\mathrm{HO}_{2}$ treatment. The 14-day 1.5-ATA $\mathrm{HO}_{2}$ regimen also reduced stress-induced increased immobility in the FST, but not in the TST, after 17 19 days of $\mathrm{HO}_{2}$ treatment (Fig. 2F J). These results suggest that the 14-day 1.5- $\mathrm{ATA}^{\mathrm{H} O}{ }_{2}$ regimen and the 14day 2.0-ATA $\mathrm{HO}_{2}$ regimen produce similar antidepressive effects shortly after $\mathrm{HO}_{2}$ treatment was ceased, and the 14-day 2.0-ATA $\mathrm{HO}_{2}$ regimen produces slightly long-lasting effects than the 14day 1.5-ATA $\mathrm{HO}_{2}$ regimen.

\section{Hyperbaric air treatment was insufficient to produce antidepressive effects in CRST mice}

Next, we investigated if the high compression and $100 \%-\mathrm{O}_{2}$ components of the 14-day 2.0-ATA $\mathrm{HO}_{2}$ regimen are essential for its antidepressive effects. In principle, the hyperbaric air at 2.0 ATA offers high compression effects and also supplies $42 \% \mathrm{O}_{2}$. Treatment with hyperbaric air at 2.0 ATA daily for $1 \mathrm{~h}$ for 14 days did not recover stress-induced reduced social interaction in the sociability test and stress-induced increased immobility in the TST and FST (Fig. 3). These results, together with the results changed by the 14-day 1.5-ATA $\mathrm{HO}_{2}$ regimen (Fig. 2F I), indicate that the 14-day $42 \% \mathrm{O}_{2}$ treatment is insufficient to produce therapeutic effects, and are consistent with the notion that hyperbaric conditions with $100 \% \mathrm{O}_{2}$ are required to produce therapeutic effects.

\section{$\mathrm{HO}_{2}$ treatment in CRST mice increased oxidative stress in the hippocampus of mice}

Recently, we reported that mice exposed to chronic stress have increased oxidative stress with the upregulation of NADPH oxidase subunits including Neutrophil cytosolic factor 1 (Ncfl, also known as p47phox) in the hippocampus and exhibit depressivelike behaviors [11,36]. Although stress-induced accumulated oxidative stress returns to near basal levels $1 \sim 2$ days after chronic 

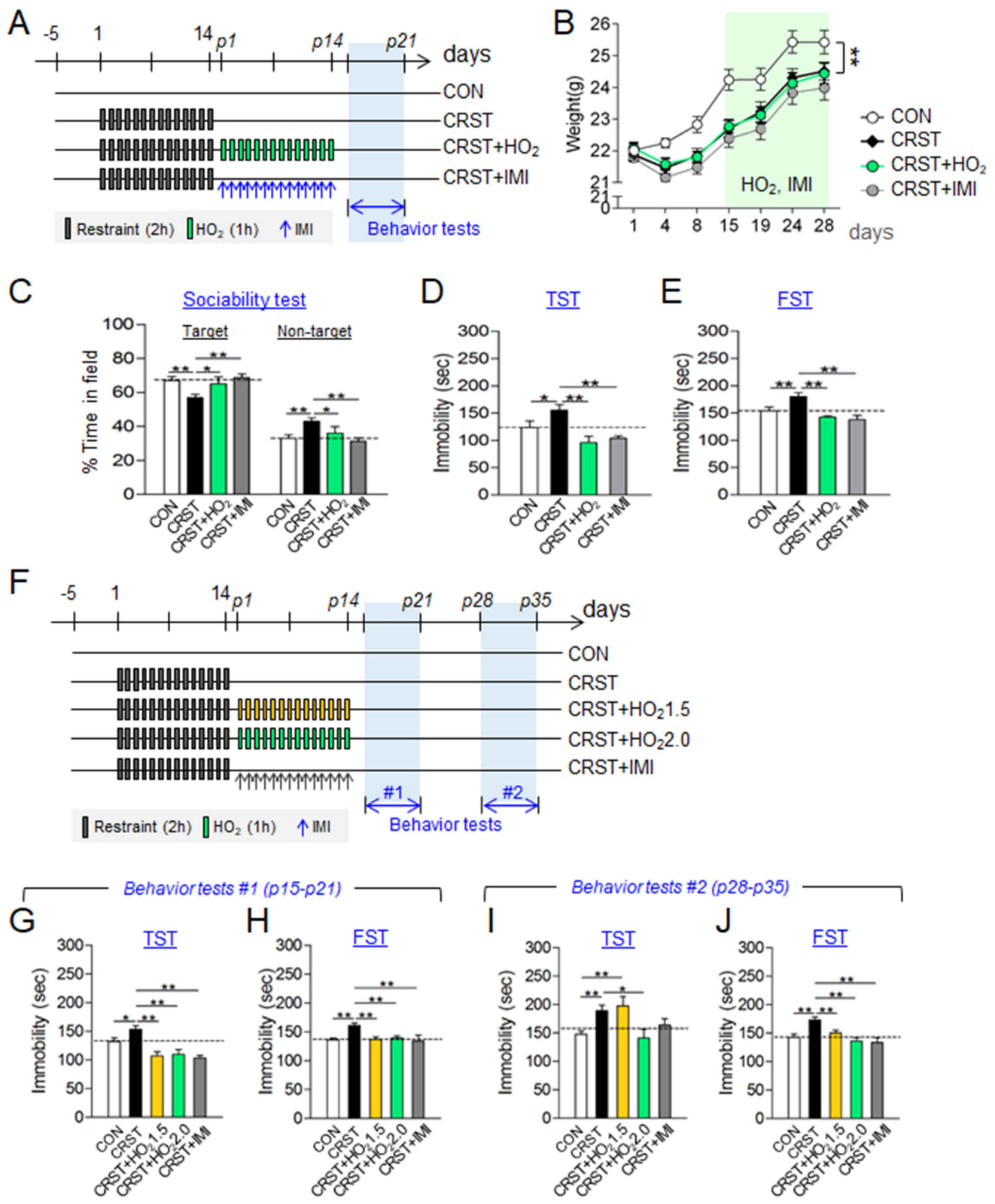

Fig. 2. Repeated and hyperbaric hyperoxygenation treatment in CRST mice produced antidepressive effects. (A) Experimental design. CRST mice were treated with $\mathrm{HO}_{2}\left(100 \% \mathrm{O}_{2}\right)$ at 2 ATA for $1 \mathrm{~h}$ daily for 14 days or imipramine (IMI; $20 \mathrm{mg} / \mathrm{kg} /$ day, i.p.) for 14 days. $\mathrm{n}=12 \sim 20$ animals per group. (B) Body weight changes during the stress phase (days 1 14) and following hyperoxygenation treatment (days 15 28, shaded box) of the indicated groups. (C E) The percent time of social interaction in the sociability test (C), and the immobility time in the TST (D) and FST (E) of the indicated groups. (F) Experimental design. CRST mice were treated with $\mathrm{HO}_{2}\left(100 \% \mathrm{O}_{2}\right)$ at $1.5 \mathrm{ATA}$ or 2.0 ATA for $1 \mathrm{~h}$ daily for 14 days $\left(\mathrm{CRST}^{\mathrm{H}} \mathrm{HO}_{2}-1.5\right.$ and CRST $+\mathrm{HO} \mathrm{O}_{2}-2.0$, respectively) or imipramine for 14 days (CRST+IMI). IMI, $20 \mathrm{mg} / \mathrm{kg} / \mathrm{day}$, i.p. Behavioral tests were performed at post-stress days $15 \sim 21$ (Exp \#1) and at post-stress days 28 35 (Exp \#2). n=10 14 animals per group. (G J) Immobility time in the TST (G, I) and FST (H,J) of the CON, CRST, CRST+HO -1.5 , $\mathrm{CRST}+\mathrm{HO}_{2}-2.0$, and CRST $+\mathrm{IMI}$ groups at post-stress days 15 21 and at post-stress days 28 35. Mean \pm SEM. ${ }^{* * *}$ difference between indicated group. ${ }^{*} \mathrm{p}<0.05,{ }^{* *} \mathrm{p}<0.01$ (one-way ANOVA and Newman-Keuls post hoc test).

restraint, CRST mice are highly sensitive to upcoming stress due to the upregulated expression of NADPH oxidase [11]. In contrast, Ncf1-/- mice exposed to chronic stress have the reduced accumulation of oxidative stress relative to the control and are resilient to stress-induced behavioral changes $[11,36]$. Hyperbaric oxygen treatment also increases oxidative stress in the brain $[31,32]$. Therefore, we investigated whether and how hyperoxygenation treatment in CRST mice, which had an upregulation of NADPH oxidase [11], accumulates oxidative stress in the brain, and if then it is mediated by NADPH oxidase. 

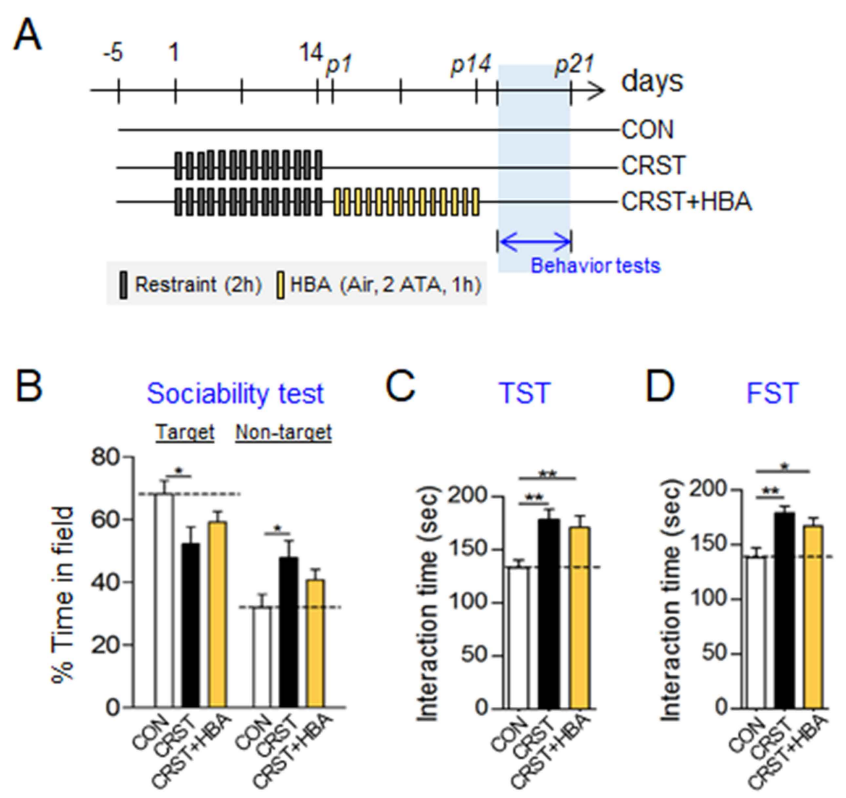

Fig. 3. Hyperbaric air treatment did not produce antidepressive effects. (A) Experimental design. CRST mice were treated with hyperbaric air (HBA) at 2.0 ATA $\left(42 \% \mathrm{O}_{2}\right)$ for 1 h daily for 14 days. $\mathrm{n}=10 \sim 14$ animals per group. (B, C) The percent time of social interaction in the sociability test (B) and the immobility time in the TST (C) and FST (D) of the indicated groups. Mean \pm SEM. ${ }^{* * *}$ difference between indicated group. ${ }^{*} \mathrm{p}<0.05$, ${ }^{* *} \mathrm{p}<0.01$ (one-way ANOVA and Newman-Keuls post hoc test).

Histological analysis of brain sections with dihydroethidium (DHE), a redox-sensitive probe that can be oxidized by superoxide to form the fluorescent product 2-hydroxyethidium (2-OH-E+), indicate that a single 1-hour $\mathrm{HO}_{2}$ treatment in naïve mice tended to increase DHE intensity in the hippocampus (Fig. 4A C) and the 7-day 1-hour $\mathrm{HO}_{2}$ regimen in naive wildtype mice significantly increased DHE intensity in the hippocampus (Fig. 4D F). Naïve $\mathrm{NcfI}^{-}$mice had the basal DHE intensity that was lower than that of wildtype mice. The 7-day 1-hour $\mathrm{HO}_{2}$ regimen in $\mathrm{Ncfl}^{-1}$ mice also increased the DHE intensity in a similar fold as that induced in WT control mice (Fig. 4D F). These results suggest that $\mathrm{HO}_{2}$ treatment increases oxidative stress, which is NADPH oxidaseindependent.

CRST mice at post-stress day 14 exhibited slightly reduced DHE intensity compared with the naïve control (Fig. 4G I). Post-stress treatment with the 14-day $\mathrm{HO}_{2}$ regimen, but not the IMI treatment, in CRST mice significantly increased DHE intensity in the hippocampus compared with CRST control (Fig. $4 \mathrm{~F} \sim \mathrm{H}$ ), and the increased DHE intensity by 14-day $\mathrm{HO}_{2}$ regimen in CRST mice was seemingly comparable to that induced by the 7-day $\mathrm{HO}_{2}$ regimen in wildtype mice (Fig. 4D F).

\section{$\mathrm{HO}_{2}$ treatment rescued stress-induced reduced mitochondrial DNA copy number in the hippocampus}

Chronic stress produces mitochondrial dysfunction in the hippocampus, including the reduction in the mitochondrial electrontransport complex activities [11] and the mitochondrial DNA (mtDNA) copy number [12]. In the present study, we investigated whether $\mathrm{HO}_{2}$ treatment changes the expression of the factors regulating mitochondrial function in the brain. Sirtuin 1 (Sirt1), peroxisome proliferator-activated receptor gamma coactivator 1-alpha (PGC-1 $\alpha$ ), nuclear respiratory factor 1 and 2 (Nrf1 and Nrf2), transcription factor A mitochondrial (Tfam; a key activator of mitochondrial transcription), and $\mathrm{NAD}(\mathrm{P}) \mathrm{H}$ :quinone acceptor oxidoreductase 1 (Nqol) are key factors regulating mitochondria biogenesis $[42,43]$. Quantitative real-time PCR (qPCR) analysis indicated that the transcript levels of Sirt1, PGC-1a, Nrf1, and Tfam tended to be reduced in the hippocampus of CRST mice compared with naive control, and the transcript levels of Nrf2 and Nqo1 were unchanged in CRST mice compared with naive control. The 14-day $\mathrm{HO}_{2}$ regimen or the 14-day IMI regimen in CRST mice did not significantly change the expression levels of those factors (Fig. 5A, B).

Next, we investigated whether the 14-day $\mathrm{HO}_{2}$ regimen changes the mtDNA copy number in the brain. qPCR analysis indicated that PCR-amplification levels of the $m t-N d 1, m t-N d 3, m t-N d 4$, and $m t-N d 5$, which are components of NADH-ubiquinone oxidoreductase (also known as complex I) [44, 45], were reduced in CRST mice compared with naive control. In contrast, the 14-day $\mathrm{HO}_{2}$ regimen in CRST mice increased the reduced level of $m t$ $N d 4$ and partially $m t-N d 5$, but not $m t-N d 1$ and $m t-N d 3$. The qPCR amplification levels of mitochondrial cytochrome $b$ (mt$C y b$, a component of the ubiquinol-cytochrome c reductase complex or complex III), mt-Coxl (a component of cytochrome c oxidase or complex IV), mt-Atp6 (a component of mitochondrially encoded ATP synthase or complex V), and mt-Dloop (the noncoding region of the mitochondrial DNA involved in mtDNA replication) $[44,45]$ were reduced in CRST mice compared with naïve control. In contrast, the 14-day $\mathrm{HO}_{2}$ regimen increased the PCR-amplification levels of those mt-DNA sequences compared with CRST mice (Fig. 5A, C). Overall, these results indicated that chronic stress decreases the mtDNA copy numbers in the hippocampus, and the 14-day $\mathrm{HO}_{2}$ regimen in CRST mice increases stress-induced reduced mtDNA copy number.

Voltage-dependent anion channel (VDAC), the most abundant mitochondrial outer membrane protein, functions as a gatekeeper for the transport of mitochondrial metabolites and calcium, and apoptosis $[46,47]$. Immunohistochemical analysis indicated that CRST mice had reduced VDAC expression in the pyramidal cell 
A

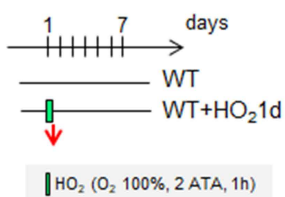

D

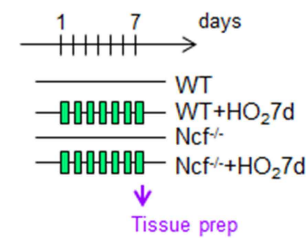

\ $\mathrm{HO}_{2}\left(\mathrm{O}_{2} 100 \%, 2\right.$ ATA, $\left.1 \mathrm{~h}\right)$

G

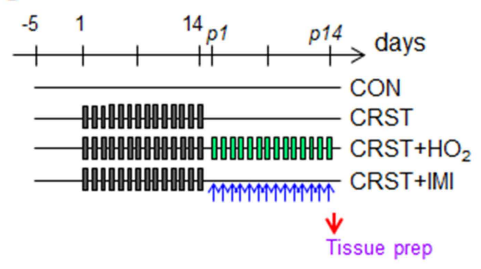

| Restraint (2h) \ $\mathrm{HO}_{2}(1 \mathrm{~h}) \quad \uparrow \mathrm{MI}$
B
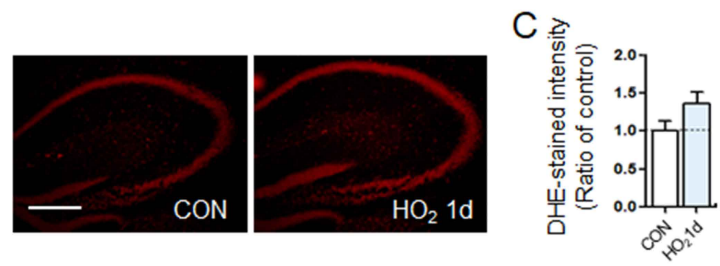

E
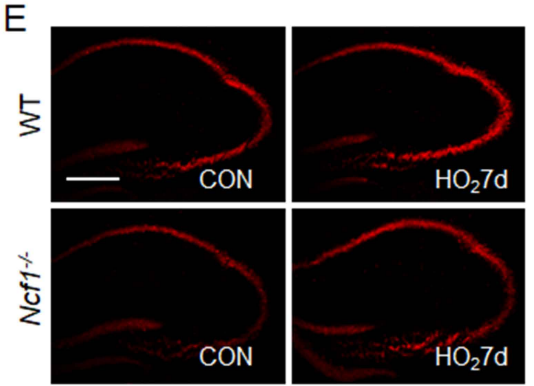

$\mathrm{F}$

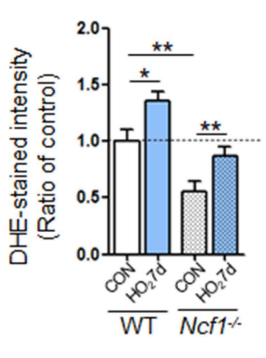

$\mathrm{H}$
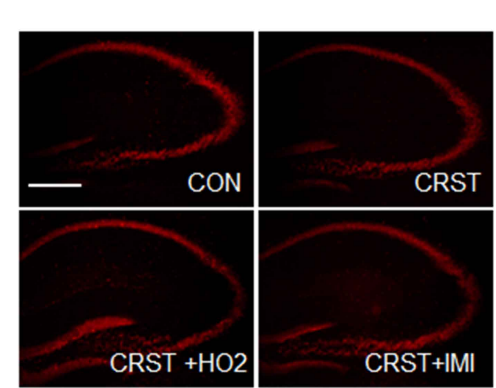

I

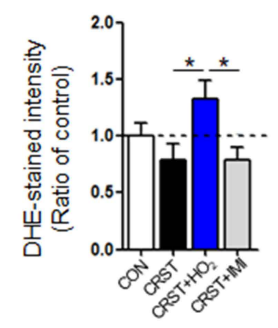

Fig. 4. $\mathrm{HO}_{2}$ treatment increased oxidative stress in the hippocampus of mice. (A C) Experimental design (A). Mice were treated with $\mathrm{HO}_{2}\left(100 \% \mathrm{O}_{2}\right)$ at $2.0 \mathrm{ATA}$ for $1 \mathrm{~h}$. Red arrow, time point for tissue preparation. Photomicrographs showing DHE-reactive oxidative stress in the hippocampus (B) of normal mice exposed to 1-h hyperoxygenation and quantification levels (C). Scale bar; $400 \mu \mathrm{m} . \mathrm{n}=8$ animals per group. (D F) Experimental design (D). Wild-type mice (WT) or Ncfl knockout mice $\left(\mathrm{Ncfl}^{-\wedge}\right)$ were treated with $\mathrm{HO}_{2}\left(100 \% \mathrm{O}_{2}\right)$ at $2.0 \mathrm{ATA}$ for $1 \mathrm{~h}$ daily for 7 days. Red arrow, time point for tissue preparation. Photomicrographs showing DHE-reactive oxidative stress in the hippocampus of wild-type mice or Ncfl KO mice exposed to 7 days of $\mathrm{HO}_{2}$ (D) and their quantification levels (E). Scale bar; $400 \mu \mathrm{m} . \mathrm{n}=8 \sim 10$ animals per group. (G I) Experimental design (G). CRST mice were treated with the 14-day $\mathrm{HO}_{2}$ treatment with $100 \% \mathrm{O}_{2}$ at 2.0 ATA or with imipramine (IMI; $20 \mathrm{mg} / \mathrm{kg} /$ day, i.p.) for 14 days. Red arrow, time point for tissue preparation. Photomicrographs showing DHE-reactive oxidative stress in the hippocampus of mice treated with the 14 days of $\mathrm{HO}_{2}$ or IMI injection $(\mathrm{H})$ and their quantification levels (I). Scale bar; $400 \mu \mathrm{m} . \mathrm{n}=4 \sim 6$ animals per group. Mean \pm SEM ${ }^{* * *}$ difference between indicated group. ${ }^{*} \mathrm{p}<0.05,{ }^{* *} \mathrm{p}<0.01$ (Student t-test; one-way ANOVA and Newman-Keuls post hoc test; two-way ANOVA and Bonferroni post hoc test).

layer of the hippocampus. In contrast, the 14 -day $\mathrm{HO}_{2}$ regime in CRST mice increased stress-induced reduced VDAC expression (Fig. 5D, E). IMI treatment in CRST mice partially increased stress-induced reduced VDAC expression, although its quantitative value was statistically insignificant (Fig. 5D, E).

Together, these results indicated that chronic stress reduces the mtDNA copy number and VDAC-dependent mitochondrial function in the hippocampus and the 14-day $\mathrm{HO}_{2}$ regimen in CRST mice rescues stress-induced mtDNA copy number and VDAC-mediated functionality of mitochondria.

\section{$\mathrm{HO}_{2}$ treatment rescued stress-induced decreased density of neuritic processes in the hippocampus in CRST mice}

Immunohistochemical analysis indicated that CRST mice had a reduction in relative MAP-2 levels stained in dendritic processes of pyramidal neurons in the stratum radiatum (SR) over total MAP2 protein levels in the hippocampus. In contrast, treatment with the 14-day $\mathrm{HO}_{2}$ regimen in CRST mice significantly increased the relative MAP-2 staining levels in the SR in the hippocampus, and IMI effect tended to increase, but its increase was not statistically significant (Fig. 6A C). CRST mice also showed a reduction in synaptophysin-stained densities in the SR in the hippocampus. In contrast, the 14-day $\mathrm{HO}_{2}$ regimen or IMI treatment reversed the reduction in synaptophysin-stained densities in the SR (Fig. 6D, E). The thickness of the pyramidal cell layer of the CA1 and CA3 stained by anti-NeuN tended to be reduced in CRST mice compared with control mice. In contrast, the 14-day $\mathrm{HO}_{2}$ regimen or IMI treatment increased the reduced thickness of the pyramidal 
A

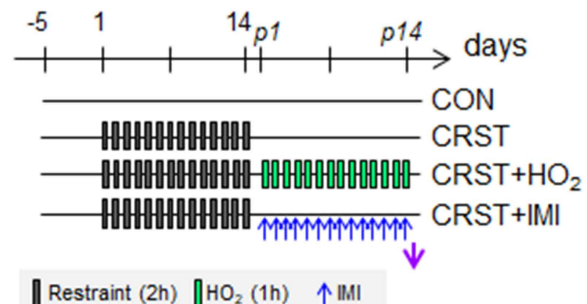

B

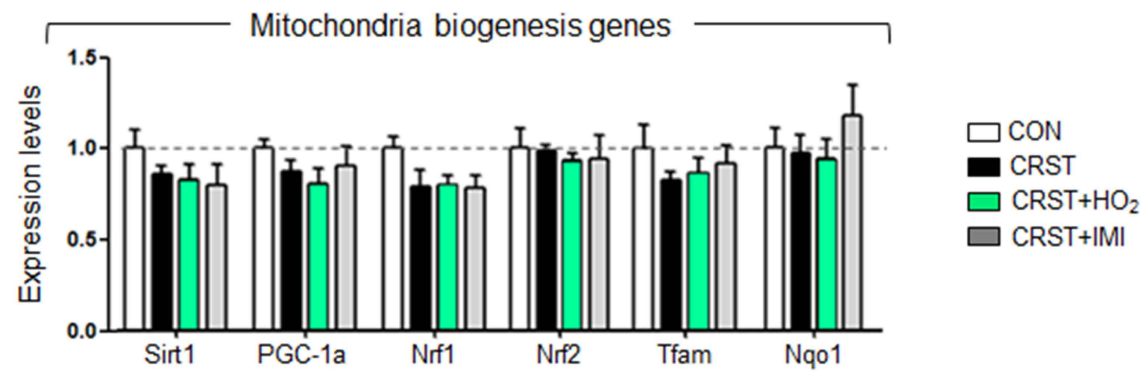

C
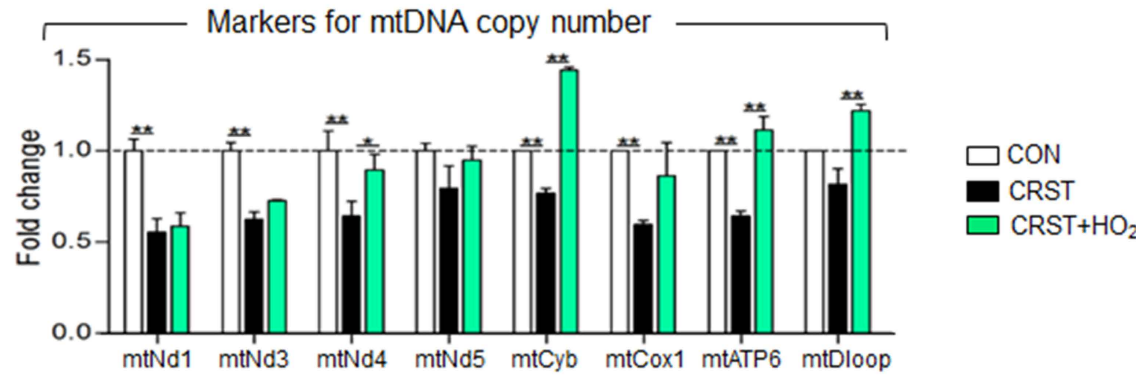

D
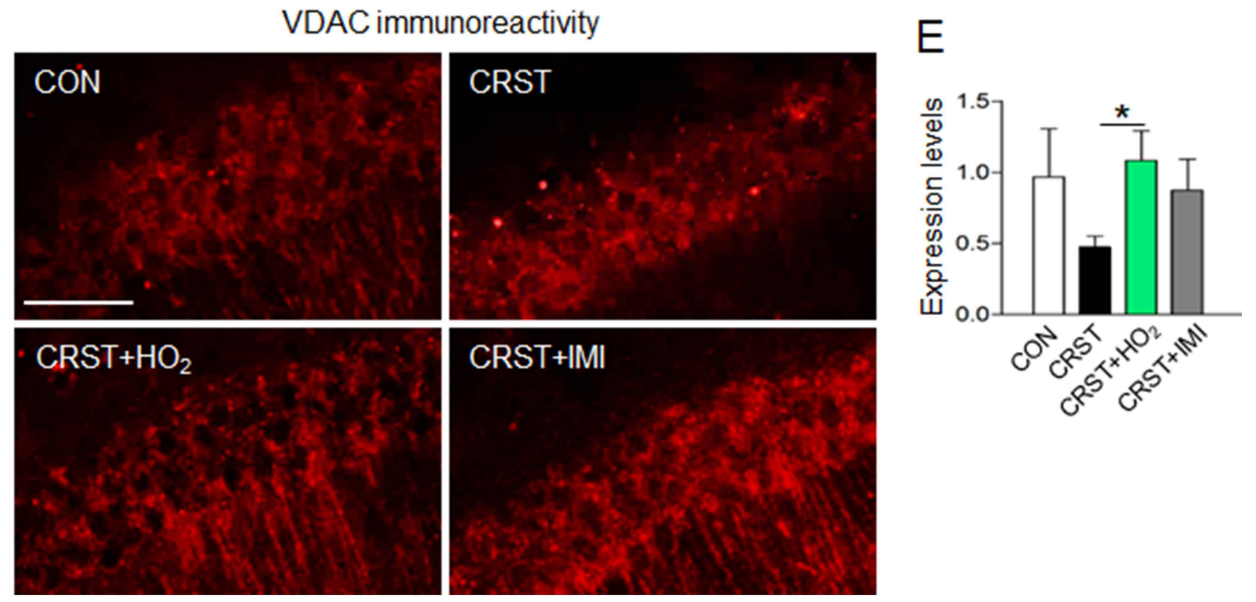

Fig. 5. $\mathrm{HO}_{2}$ treatment rescued stress-induced reduced mtDNA copy numbers in the hippocampus. (A) Experimental design. CRST mice were treated with the 14-day, 2.0-ATA $\mathrm{HO}_{2}$ regimen or imipramine (IMI; $20 \mathrm{mg} / \mathrm{kg} /$ day, i.p.) as depicted. $\mathrm{HO}_{2}: 100 \% \mathrm{O}_{2}$ was treated for $1 \mathrm{~h}$ daily for indicated days. Red arrow, time point for tissue preparation. (B) Transcript levels of Sirt1, PGC-1a, Nrf1, Nrf2, Tfam, and Nqo1 in the hippocampus of control, CRST mice, CRST mice treated with the 14 -day $\mathrm{HO}_{2}$ regimen, and CRST mice treated with IMI. $\mathrm{n}=6 \sim 8$ animals per group and 6 PCR repeats per group. (C) PCR amplification levels of the mtDNA copy number markers of $m t-N d 1, m t-N d 3, m t-N d 4, m t-N d 5, m t-C y b, m t$-Cox $1, m t-A t p 6$, and mt-Dloop in the hippocampus of control, CRST mice, and CRST mice treated with the 14-day $\mathrm{HO}_{2}$ regimen. $\mathrm{n}=8$ animals per group and $4 \sim 6$ PCR repeats for each. (D, E) Photomicrographs showing VDAC expression in the pyramidal cell layer of the CA1 of the hippocampus (D) of the indicated groups. Quantification of VDAC expression levels (E). Scale bar; $50 \mu \mathrm{m} . \mathrm{n}=6$ animals per group. Mean \pm SEM. ${ }^{* * *}$ difference between indicated group. ${ }^{*} \mathrm{p}<0.05,{ }^{* *} \mathrm{p}<0.01$ (one-way ANOVA and Newman-Keuls post hoc test). 

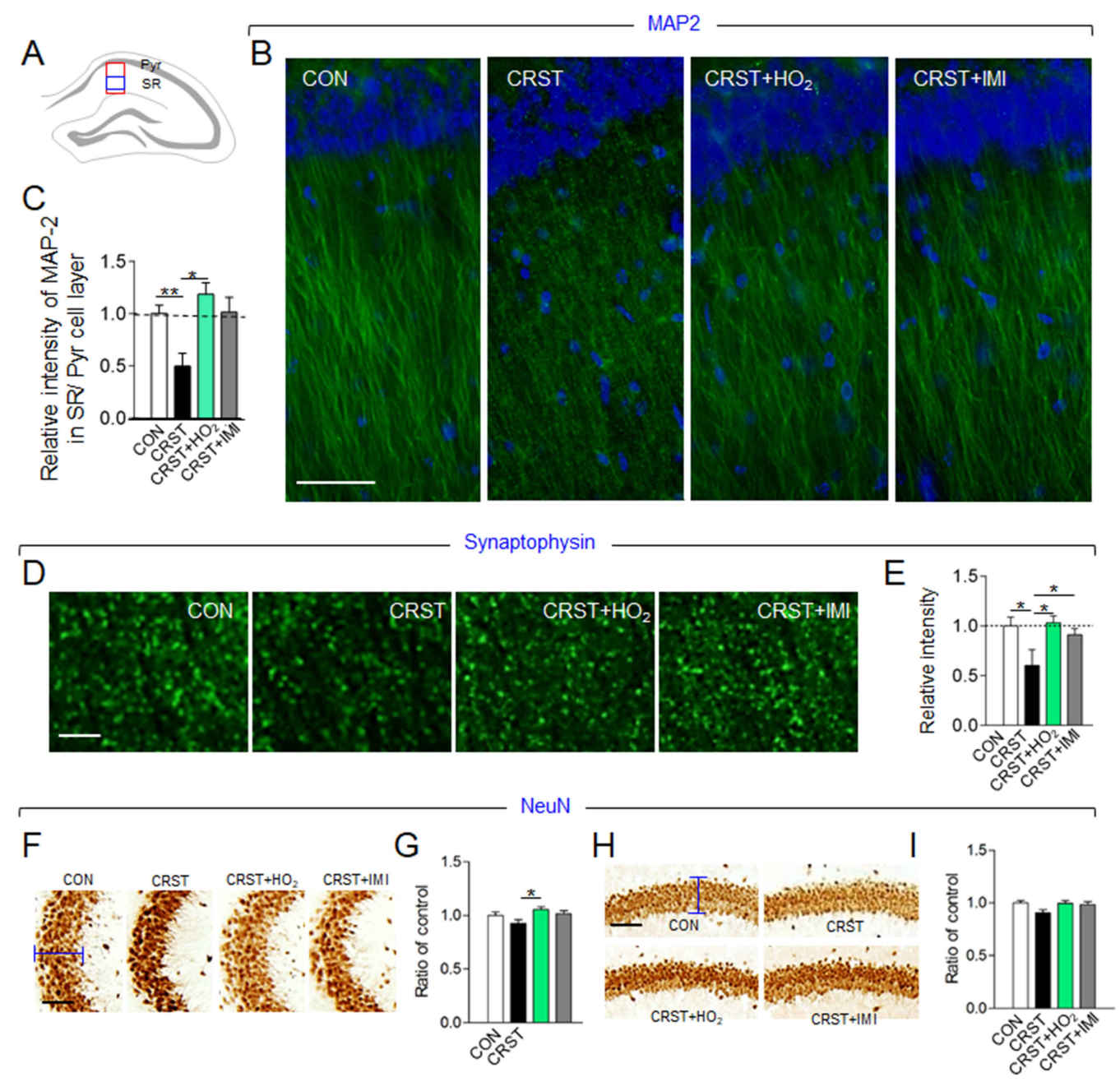

Fig. 6. $\mathrm{HO}_{2}$ treatment rescued stress-induced decreased density of neuritic processes of hippocampal neurons in CRST mice. (A E) Diagram for the regions examined for immunohistochemical analyses (A). Red box in A is the regions for the images in B, and blue box is for the images in D. Pyr, pyramidal cell layer; SR, stratum radiatum. Photomicrographs showing MAP-2-stained dendritic processes of pyramidal neurons in the SR (B) of the CA1 region of the indicated groups. Scale bar; $50 \mu \mathrm{m}$. Quantification levels of the relative intensity of MAP-2-stained dendritic processes in the SR over MAP2-staining levels in the CA1 pyramidal cell layer (C). Green, MAP-2; Blue, DAPI. Photomicrographs showing synaptophysin-stained puncta in the SR in the hippocampus (D). Scale bar; $40 \mu \mathrm{m}$. Quantification levels of synaptophysin staining levels in the SR of the indicated groups (E). $\mathrm{n}=6$ animals per group. (F I) Photomicrographs showing NeuN-stained pyramidal cell layers in the CA3 (F) and CA1 (H) of the hippocampus of the indicated groups. Quantification levels of the thickness of CA3 (G) and CA1 (I) pyramidal cell layers. Scale bar; $50 \mu \mathrm{m}$. n=8 animals per group. Mean \pm SEM. ${ }^{* * *}$ difference between indicated group. ${ }^{*} \mathrm{p}<0.05,{ }^{\star *} \mathrm{p}<0.01$ (one-way ANOVA and Newman-Keuls post hoc test).

cell layer (Fig. 6E H).

\section{$\mathrm{HO}_{2}$ treatment increased stress-induced reduced \\ neurogenesis in the hippocampus in CRST mice}

Immunohistochemical analysis indicated that CRST mice had decreased numbers of Ki67-positive cells (Ki67; a proliferating cell marker) and doublecortin (DCX)-positive cells (DCX; a marker of neuronal precursor) in the dentate gyrus. In contrast, the 14-day $\mathrm{HO}_{2}$ regimen or IMI treatment in CRST mice increased stress-induced reduced numbers of Ki67-positive cells and DCX-positive cells (Fig. 7).

\section{DISCUSSION}

In the present study, we demonstrated that the 14-day hyperoxygenation treatment with $100 \% \mathrm{O}_{2}$ at 2.0 ATA rescued stressinduced depressive-like behaviors and remedied behaviors by the 14-day $\mathrm{HO}_{2}$ regimen stabled for more than 3 weeks from the end of $\mathrm{HO}_{2}$ treatment (Fig. 1, 2). In contrast, the shorter duration (3, 5 or 7 days) $\mathrm{HO}_{2}$ regimens were ineffective or partially effective (Fig. 1). Interestingly, the 14-day treatment with $100 \% \mathrm{O}_{2}$ at 1.5 ATA produced antidepressive effects as the 14-day 2.0-ATA $\mathrm{HO}_{2}$ regimen after $3 \sim 5$ days of $\mathrm{HO}_{2}$ treatment. However, antidepressive 
A

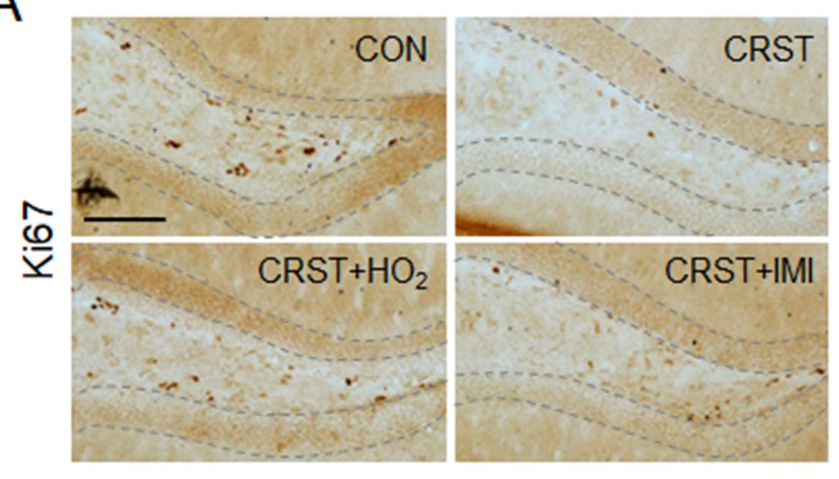

C

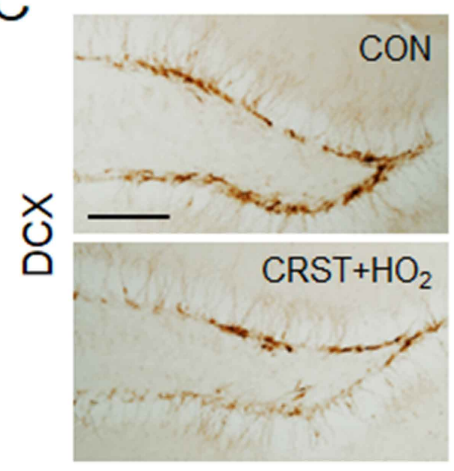

B

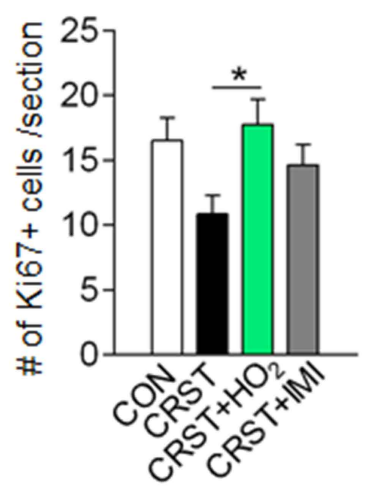

D

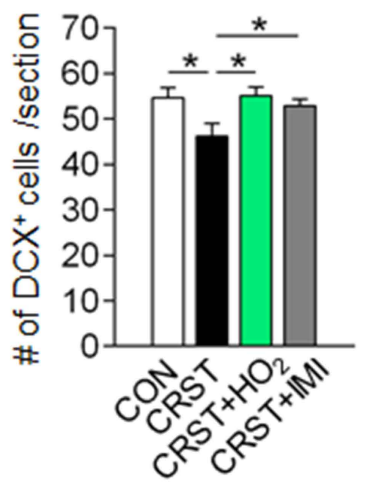

Fig. 7. $\mathrm{HO}_{2}$ treatment increased the reduced neurogenesis in the hippocampus of CRST mice. (A, B) Photomicrographs showing anti-Ki67-stained cells in the dentate gyrus (A) of control, CRST mice, CRST mice treated with $\mathrm{HO}_{2}\left(100 \% \mathrm{O}_{2}\right)$ at 2.0 ATA for 1 h daily for 14 days and CRST mice treated with imipramine (IMI). Quantification of anti-Ki67-positive cells in the dentate gyrus. Scale bar; $200 \mu \mathrm{m}$. (C, D) Photomicrographs showing anti-doublecortin (DCX)-stained cells in the dentate gyrus (A) of control, CRST mice, CRST mice treated with $\mathrm{HO}_{2}\left(100 \% \mathrm{O}_{2}\right)$ at 2.0 ATA for $1 \mathrm{~h}$ daily for 14 days and CRST mice treated with imipramine (IMI). Quantification of anti-DCX-positive cells in the dentate gyrus. Scale bar; $200 \mu \mathrm{m}$. Mean \pm SEM ( $\mathrm{n}=7 \sim 8$ animals per group). ${ }^{* * *}$ difference between indicated group. ${ }^{*} \mathrm{p}<0.05,{ }^{* *} \mathrm{p}<0.01$ (one-way ANOVA and Newman-Keuls post hoc test).

effects produced by the 1.5 ATA regimen partially faded away after 17 19 days of $\mathrm{HO}_{2}$ treatment (Fig. 2F J). The 14-day hyperbaric air treatment at 2.0 ATA, which provides $42 \% \mathrm{O}_{2}$, was ineffective in the all behavioral tests applied (Fig. 3). Together, these results support that the 14 -day $\mathrm{HO}_{2}$ treatment with $100 \% \mathrm{O}_{2}$ at 2.0 ATA is effective to stably reverse stress-induced depressive-like behaviors, whereas the shorter duration 2.0-ATA regimen or the 14-day 1.5-ATA regimen is ineffective or partially effective. Recently, we reported that $\mathrm{HO}_{2}$ treatment with $100 \% \mathrm{O}_{2}$ at 2.0 ATA for 28 days in Tg-APP/PS1 Alzheimer disease model mice markedly reduced plaque deposition in the brain and improved cognitive deficits [30, 33 . However, the hyperbaric air treatment at 2.0 ATA $\left(42 \% \mathrm{O}_{2}\right)$ for 28 days did not rescue cognitive deficits of Tg-APP/PS1 mice at all [30]. These results suggest that $A \beta$-induced neuropathology and stress-induced maladaptive changes can be relieved by treatment with $100 \% \mathrm{O}_{2}$ at 2.0 ATA for a long duration (ex, 14 days), whereas the 14-day treatment with $42 \% \mathrm{O}_{2}$ is far from the effective condition. These results also suggest that although high compression itself is not essential, it is required to securely deliver molecular oxygen to neural cells in the brain. The fact that the 14-day $\mathrm{HO}_{2}$ regimen produced persistent antidepressive effects whereas the shorter duration $\mathrm{HO}_{2}$ regimen produced only partial effects suggests that repeated availability of sufficient levels of molecular oxygen is critical to remedy stress-induced maladaptive changes. The 2.0 ATA regimen should increase molecular oxygen availability in brain cells higher than that achieved by 1.5 ATA regimen.

VDAC is encoded by nuclear DNA, and VDAC protein is translocated into the mitochondrial outer membrane, where it regulates transport of metabolites and $\mathrm{Ca}^{+2}$, acting as a gate keeper of functional mitochondria [46, 47]. Chronic stress reduced VDAC expression in the pyramidal cell layer in the hippocampus, and the 14-day $\mathrm{HO}_{2} \mathrm{t}$ regimen in CRST mice reversed stress-induced reduced expression of VDAC (Fig. 5), suggesting that chronic stress causes mitochondrial dysfunction and the 14-day $\mathrm{HO}_{2}$ regimen restores the reduced VDAC-mediated mitochondrial function. Chronic stress decreased mtDNA copy numbers in the hippocampus. In contrast, the 14-day $\mathrm{HO}_{2}$ regimen in CRST mice reversed stress-induced reduction in the mtDNA copy number (Fig. 5). 
The decrease of mitochondrial copy numbers and reduced VDAC expression in the brain of CRST mice might be responsible for the reduction of mitochondrial electron-transport complex activities induced by CRST [11]. Furthermore, the reduced mitochondrial copy numbers and resulting mitochondrial-mediated oxidative stress could affect OXPHOS capacity, and produce energy crisis and nuclear gene expression alteration [48, 49]. Conversely, $\mathrm{HO}_{2}$ treatment in CRST mice restored stress-induced reduced levels of mtDNA copy number markers, including $\mathrm{mtNd} 5$, mtCyb, mtATP6, and mtDloop and VDAC expression, although stress-induced reduced levels of $\mathrm{mtNd} 1$ and $\mathrm{mtNd} 3$ were not significantly changed (Fig. 5C E). Expression levels of the mitochondrial biogenesis genes, including PGC-1 $\alpha, \mathrm{Nrf1} / 2$, Tfam and Nqo1 were not significantly changed by CRST and hyperoxygenation treatment (Fig. 5B). How hyperoxygenation produces the upregulation of mtDNA replication, and mitochondrial dynamics and increased levels of mitochondrial proteins remains to be explored in the future. Our results suggest that the underlying mechanism should be sensitively changed by stress and hyperoxygenation states.

Hyperoxygenation treatment produces diverse cellular and genomic responses in various models. In HT22 cultured neuronal cells, hyperoxygenation condition provided with perfluorodecalin (PFD), a synthetic material that noncovalently dissolves large amounts of $\mathrm{O}_{2}$ and has been used as an $\mathrm{O}_{2}$ source [50], reversed $\mathrm{A} \beta 42$-induced increase in the expression of hypoxia inducible factor 1a (Hif-1a), vascular endothelial growth factor A (Vegf-a), heme oxygenase 1 (Hmox 1 ), and pyruvate dehydrogenase kinase 1 (Pdk1) [30], and A $\beta 42$-induced decrease in the expression of $B d n f$, $N t 3, N t 4 / 5$, and Trkb [30]. Consistent with these in vitro results, hyperoxygenation treatment with $100 \% \mathrm{O}_{2}$ at 2.0 ATA for 1 h daily for 28 days reversed the enhanced expression of Hif-1a, Hmoxl, and $P d k 2$ and the decreased expression of $B d n f, N t 3$, and $N t 4 / 5$ in the hippocampus of Tg-APP/PS1 mice [30]. In mice with subcutaneously implanted Matrigel plugs, hyperoxygenation treatment at 2.8 ATA for 90 min daily for 10 days produced a trophic effect on migration of vasculogenic bone marrow-derived stem cells via oxidative stress-mediated activation of the Hif-1/2-regulated pathway including the induction of Hif- $1 / 2$, mitogen-activated protein kinase (MAPK) 1/2, thioredoxin (TrX) system, Nrf2, and $\operatorname{Vegf}[51]$. These results suggest that hyperoxygenation induces cellular and genomic responses by increased availability of molecular oxygen. In fact, $\mathrm{HO}_{2}$ treatment at $2.0 \mathrm{ATA}$ in animals has been reported to increase the $\mathrm{O}_{2}$ tension in the brain tissues by 7-10 fold compared with the $\mathrm{O}_{2}$ tension under ambient room air [52-54]. Hyperoxygenation therapy in brain injury produced neuroprotective effects in association with preservation of mitochondrial function [54, 55]. Because high oxygen levels could oxidize the sulfur-con- taining amino acids cysteine and methionine in cellular proteins [56], increased availability of $\mathrm{O}_{2}$ in brain cells likely facilitates the functionality of cellular and nuclear factors to increase expression of neurotrophic expression [30] or mitochondrial genes (Fig. 5). It could be valuable to test this hypothesis in the future.

Hyperbaric oxygen treatment increases oxidative stress [31, 57]. Since oxidative stress produces harmful effects in the pathogenesis of various neural diseases, hyperoxygenation-induced oxidative stress has hampered widespread acceptance of the use of hyperbaric oxygen therapy $[57,58]$. However, several lines of evidence suggest that a certain level of oxidative stress induced by hyperoxygenation is a critical part of therapeutic effects of hyperbaric oxygen therapy $[31,57]$. Co-treatment with $\mathrm{N}$-acetylcysteine (an anti-oxidant) blocked hyperoxygenation effects on the induction of a trophic effect and proliferation of bone marrow-derived stem cells [51]. $\mathrm{HO}_{2}$ treatment at 2.4 ATA for 90 min daily for 7 14 days in rats with ischemic tissue injury increased the antioxidant enzymes $\mathrm{Cu} / \mathrm{Zn}$-superoxide dismutase, catalase, and glutathione peroxidase, and decreased the pro-oxidant enzymes iNOS and gp91phox, thereby decreasing oxygen radical accumulation in ischemic wound tissue, whereas co-treatment with $\mathrm{N}$-acetylcysteine during hyperoxygenation blocked those changes [59]. Furthermore, hyperoxygenation-induced oxidative stress could reduce pro-inflammatory cytokines and increases growth factors [56]. Repeated restraint increases oxidative stress during the stress phase along with upregulation of NADPH oxidase, and as a result CRST mice exhibit exaggerated oxidative responses to upcoming stress insults $[11,36]$. As demonstrated in the present study, $\mathrm{HO}_{2}$ treatment at 2.0 ATA in normal naïve mice increased oxidative stress in the hippocampus, in which NADPH oxidase was not a critical player (Fig. $4 \mathrm{~A} \sim \mathrm{F}$ ) and that $\mathrm{HO}_{2}$ treatment in CRST mice increased oxidative stress in a level similar to that induced by $\mathrm{HO}_{2}$ treatment in normal mice (Fig. 4D I). Therefore, we speculate that the feasibility of $\mathrm{HO}_{2}$ treatment in resolving stress-induced depressive phenotypes (Fig. 1 3) is possible in part due to the differential mechanisms in oxidative stress production by CRST and $\mathrm{HO}_{2}$ treatment; $\mathrm{NADPH}$ oxidase-dependent mechanism in CRST vs. NADPH oxidaseindependent mechanism in $\mathrm{HO}_{2}$ treatment. It is possible that $\mathrm{HO}_{2}$ treatment induces anti-oxidative enzymes, such as $\mathrm{Cu} / \mathrm{Zn}$-superoxide dismutase, catalase, and glutathione peroxidase [57], and growth factors, such as BDNF and NT3, and NT4/5 [31, 37, 57], and those changes could contribute to antagonize stress-induced maladaptive changes in oxidative stress controls.

Another safety concern in hyperoxygenation therapy is related with potential oxygen toxicity referring to oxygen poisoning. Prolonged hyperoxygenation may cause alveolar epithelial and alveolar capillary endothelial membrane injury, and the tiny air 
sacs (alveoli) in the lung may be filled with fluid and are no longer inflated, resulting in pulmonary dysfunction [60]. However, in preclinical and clinical studies, hyperoxygenation therapy at 1.5 3 ATA in a controlled manner has been reported to be safe and produced therapeutic effects in various acute and chronic models of diseases $[24,61,62]$. In the present study, we found no evidence that repeated $\mathrm{HO}_{2}$ treatment at 2.0 ATA in normal mice and CRST mice produces any signs of harmful effects. Nonetheless, diverse hyperoxygenation conditions and potential hyperoxygenationrelated risks in various clinical applications need to be explored and tested in more detail.

\section{ACKNOWLEDGEMENTS}

This research was supported by a grant (2021R1A2B5B02002245) from the Ministry of Science, ICT and Future Planning, Republic of Korea.

\section{REFERENCES}

1. de Kloet ER, Joëls M, Holsboer F (2005) Stress and the brain: from adaptation to disease. Nat Rev Neurosci 6:463-475.

2. Ulrich-Lai YM, Herman JP (2009) Neural regulation of endocrine and autonomic stress responses. Nat Rev Neurosci 10:397-409.

3. Herman JP, McKlveen JM, Ghosal S, Kopp B, Wulsin A, Makinson R, Scheimann J, Myers B (2016) Regulation of the hypothalamic-pituitary-adrenocortical stress response. Compr Physiol 6:603-621.

4. McKay LI, Cidlowski JA (2003) Physiologic and pharmacologic effects of corticosteroids. In: Holland-Frei cancer medicine (Kufe DW, Pollock RE, Weichselbaum RR, Bast RC Jr, Gansler TS, Holland JF, Frei E III, eds), 6th ed. BC Decker, Hamilton, ON.

5. Oster H, Challet E, Ott V, Arvat E, de Kloet ER, Dijk DJ, Lightman S, Vgontzas A, Van Cauter E (2017) The functional and clinical significance of the 24-hour rhythm of circulating glucocorticoids. Endocr Rev 38:3-45.

6. Maydych V (2019) The interplay between stress, inflammation, and emotional attention: relevance for depression. Front Neurosci 13:384.

7. Willner P (2005) Chronic mild stress (CMS) revisited: consistency and behavioural-neurobiological concordance in the effects of CMS. Neuropsychobiology 52:90-110.

8. Seo JS, Park JY, Choi J, Kim TK, Shin JH, Lee JK, Han PL (2012) NADPH oxidase mediates depressive behavior induced by chronic stress in mice. J Neurosci 32:9690-9699.
9. Planchez B, Surget A, Belzung C (2019) Animal models of major depression: drawbacks and challenges. J Neural Transm (Vienna) 126:1383-1408.

10. Madrigal JL, Olivenza R, Moro MA, Lizasoain I, Lorenzo P, Rodrigo J, Leza JC (2001) Glutathione depletion, lipid peroxidation and mitochondrial dysfunction are induced by chronic stress in rat brain. Neuropsychopharmacology 24:420-429.

11. Seo JS, Lee KW, Kim TK, Baek IS, Im JY, Han PL (2011) Behavioral stress causes mitochondrial dysfunction via ABAD up-regulation and aggravates plaque pathology in the brain of a mouse model of Alzheimer disease. Free Radic Biol Med 50:1526-1535.

12. Picard M, McEwen BS (2018) Psychological stress and mitochondria: a systematic review. Psychosom Med 80:141-153.

13. Brown ES, Rush AJ, McEwen BS (1999) Hippocampal remodeling and damage by corticosteroids: implications for mood disorders. Neuropsychopharmacology 21:474-484.

14. Krugers HJ, Lucassen PJ, Karst H, Joëls M (2010) Chronic stress effects on hippocampal structure and synaptic function: relevance for depression and normalization by antiglucocorticoid treatment. Front Synaptic Neurosci 2:24.

15. Sousa N, Lukoyanov NV, Madeira MD, Almeida OF, PaulaBarbosa MM (2000) Reorganization of the morphology of hippocampal neurites and synapses after stress-induced damage correlates with behavioral improvement. Neuroscience 97:253-266.

16. Pham K, Nacher J, Hof PR, McEwen BS (2003) Repeated restraint stress suppresses neurogenesis and induces biphasic PSA-NCAM expression in the adult rat dentate gyrus. Eur J Neurosci 17:879-886.

17. Yun J, Koike H, Ibi D, Toth E, Mizoguchi H, Nitta A, Yoneyama M, Ogita K, Yoneda Y, Nabeshima T, Nagai T, Yamada K (2010) Chronic restraint stress impairs neurogenesis and hippocampus-dependent fear memory in mice: possible involvement of a brain-specific transcription factor Npas4. J Neurochem 114:1840-1851.

18. Schoenfeld TJ, Gould E (2012) Stress, stress hormones, and adult neurogenesis. Exp Neurol 233:12-21.

19. Grønli J, Bramham C, Murison R, Kanhema T, Fiske E, Bjorvatn B, Ursin R, Portas CM (2006) Chronic mild stress inhibits BDNF protein expression and CREB activation in the dentate gyrus but not in the hippocampus proper. Pharmacol Biochem Behav 85:842-849.

20. Taliaz D, Stall N, Dar DE, Zangen A (2010) Knockdown of brain-derived neurotrophic factor in specific brain sites precipitates behaviors associated with depression and reduces neurogenesis. Mol Psychiatry 15:80-92. 
21. Govindarajan A, Rao BS, Nair D, Trinh M, Mawjee N, Tonegawa S, Chattarji S (2006) Transgenic brain-derived neurotrophic factor expression causes both anxiogenic and antidepressant effects. Proc Natl Acad Sci U S A 103:1320813213.

22. Lee EH, Han PL (2019) Reciprocal interactions across and within multiple levels of monoamine and cortico-limbic systems in stress-induced depression: a systematic review. Neurosci Biobehav Rev 101:13-31.

23. Huang L, Obenaus A (2011) Hyperbaric oxygen therapy for traumatic brain injury. Med Gas Res 1:21.

24. Hu Q, Manaenko A, Xu T, Guo Z, Tang J, Zhang JH (2016) Hyperbaric oxygen therapy for traumatic brain injury: benchto-bedside. Med Gas Res 6:102-110.

25. Baynosa RC, Naig AL, Murphy PS, Fang XH, Stephenson LL, Khiabani KT, Wang WZ, Zamboni WA (2013) The effect of hyperbaric oxygen on nitric oxide synthase activity and expression in ischemia-reperfusion injury. J Surg Res 183:355361.

26. Hu Q, Liang X, Chen D, Chen Y, Doycheva D, Tang J, Tang J, Zhang JH (2014) Delayed hyperbaric oxygen therapy promotes neurogenesis through reactive oxygen species/hypoxia-inducible factor- $1 \alpha / \beta$-catenin pathway in middle cerebral artery occlusion rats. Stroke 45:1807-1814.

27. Zhang T, Yang QW, Wang SN, Wang JZ, Wang Q, Wang Y, Luo YJ (2010) Hyperbaric oxygen therapy improves neurogenesis and brain blood supply in piriform cortex in rats with vascular dementia. Brain Inj 24:1350-1357.

28. Mu J, Krafft PR, Zhang JH (2011) Hyperbaric oxygen therapy promotes neurogenesis: where do we stand? Med Gas Res $1: 14$.

29. Schulze J, Kaiser O, Paasche G, Lamm H, Pich A, Hoffmann A, Lenarz T, Warnecke A (2017) Effect of hyperbaric oxygen on BDNF-release and neuroprotection: investigations with human mesenchymal stem cells and genetically modified NIH3T3 fibroblasts as putative cell therapeutics. PLoS One 12:e178182.

30. Choi J, Kwon HJ, Lee JE, Lee Y, Seoh JY, Han PL (2019) Hyperoxygenation revitalizes Alzheimer's disease pathology through the upregulation of neurotrophic factors. Aging Cell 18:e12888.

31. Thom SR (2009) Oxidative stress is fundamental to hyperbaric oxygen therapy. J Appl Physiol (1985) 106:988-995.

32. Choudhury R (2018) Hypoxia and hyperbaric oxygen therapy: a review. Int J Gen Med 11:431-442.

33. Choi J, Kwon H, Han PL (2021) Hyperoxygenation treatment reduces beta-amyloid deposition via MeCP2-dependent upregulation of MMP-2 and MMP-9 in the hippocampus of Tg-APP/PS1 mice. Exp Neurobiol 30:294-307.

34. Tezgin D, Giardina C, Perdrizet GA, Hightower LE (2020) The effect of hyperbaric oxygen on mitochondrial and glycolytic energy metabolism: the caloristasis concept. Cell Stress Chaperones 25:667-677.

35. Huang CK, Zhan L, Hannigan MO, Ai Y, Leto TL (2000) P47(phox)-deficient NADPH oxidase defect in neutrophils of diabetic mouse strains, C57BL/6J-m db/db and $\mathrm{db} /+$. J Leukoc Biol 67:210-215.

36. Lee JE, Kwon HJ, Choi J, Seo JS, Han PL (2020) Aging increases vulnerability to stress-induced depression via upregulation of NADPH oxidase in mice. Commun Biol 3:292.

37. Choi J, Kim JE, Kim TK, Park JY, Lee JE, Kim H, Lee EH, Han PL (2015) TRH and TRH receptor system in the basolateral amygdala mediate stress-induced depression-like behaviors. Neuropharmacology 97:346-356.

38. Kim HR, Kim JH, Choi EJ, Lee YK, Kie JH, Jang MH, Seoh JY (2014) Hyperoxygenation attenuated a murine model of atopic dermatitis through raising skin level of ROS. PLoS One 9:e109297.

39. Quiros PM, Goyal A, Jha P, Auwerx J (2017) Analysis of mtDNA/nDNA Ratio in Mice. Curr Protoc Mouse Biol 7:47-54.

40. Kim TK, Kim JE, Park JY, Lee JE, Choi J, Kim H, Lee EH, Kim SW, Lee JK, Kang HS, Han PL (2015) Antidepressant effects of exercise are produced via suppression of hypocretin/orexin and melanin-concentrating hormone in the basolateral amygdala. Neurobiol Dis 79:59-69.

41. Kim TK, Lee JE, Kim JE, Park JY, Choi J, Kim H, Lee EH, Han PL (2016) G9a-mediated regulation of OXT and AVP expression in the basolateral amygdala mediates stress-induced lasting behavioral depression and its reversal by exercise. Mol Neurobiol 53:2843-2856.

42. Ventura-Clapier R, Garnier A, Veksler V (2008) Transcriptional control of mitochondrial biogenesis: the central role of PGC-1alpha. Cardiovasc Res 79:208-217.

43. Gureev AP, Shaforostova EA, Popov VN (2019) Regulation of mitochondrial biogenesis as a way for active longevity: interaction between the Nrf2 and PGC-1 $\alpha$ signaling pathways. Front Genet 10:435.

44. Taanman JW (1999) The mitochondrial genome: structure, transcription, translation and replication. Biochim Biophys Acta 1410:103-123.

45. Chinnery PF, Hudson G (2013) Mitochondrial genetics. Br Med Bull 106:135-159.

46. Shoshan-Barmatz V, Ben-Hail D (2012) VDAC, a multifunctional mitochondrial protein as a pharmacological target. 
Mitochondrion 12:24-34.

47. Camara AKS, Zhou Y, Wen PC, Tajkhorshid E, Kwok WM (2017) Mitochondrial VDAC1: a key gatekeeper as potential therapeutic target. Front Physiol 8:460.

48. Filograna R, Mennuni M, Alsina D, Larsson NG (2021) Mitochondrial DNA copy number in human disease: the more the better? FEBS Lett 595:976-1002.

49. Castellani CA, Longchamps RJ, Sun J, Guallar E, Arking DE (2020) Thinking outside the nucleus: mitochondrial DNA copy number in health and disease. Mitochondrion 53:214223.

50. Lowe KC, Davey MR, Power JB (1998) Perfluorochemicals: their applications and benefits to cell culture. Trends Biotechnol 16:272-277.

51. Milovanova TN, Bhopale VM, Sorokina EM, Moore JS, Hunt TK, Hauer-Jensen M, Velazquez OC, Thom SR (2009) Hyperbaric oxygen stimulates vasculogenic stem cell growth and differentiation in vivo. J Appl Physiol (1985) 106:711-728.

52. Demchenko IT, Luchakov YI, Moskvin AN, Gutsaeva DR, Allen BW, Thalmann ED, Piantadosi CA (2005) Cerebral blood flow and brain oxygenation in rats breathing oxygen under pressure. J Cereb Blood Flow Metab 25:1288-1300.

53. Barata P, Cervaens M, Resende R, Camacho O, Marques F (2011) Hyperbaric oxygen effects on sports injuries. Ther Adv Musculoskelet Dis 3:111-121.

54. McKeown SR (2014) Defining normoxia, physoxia and hypoxia in tumours-implications for treatment response. Br J Radiol 87:20130676.

55. Palzur E, Zaaroor M, Vlodavsky E, Milman F, Soustiel JF
(2008) Neuroprotective effect of hyperbaric oxygen therapy in brain injury is mediated by preservation of mitochondrial membrane properties. Brain Res 1221:126-133.

56. Sanchez R, Riddle M, Woo J, Momand J (2008) Prediction of reversibly oxidized protein cysteine thiols using protein structure properties. Protein Sci 17:473-481.

57. De Wolde SD, Hulskes RH, Weenink RP, Hollmann MW, Van Hulst RA (2021) The effects of hyperbaric oxygenation on oxidative stress, inflammation and angiogenesis. Biomolecules 11:1210.

58. Oter S, Korkmaz A, Topal T, Ozcan O, Sadir S, Ozler M, Ogur R, Bilgic H (2005) Correlation between hyperbaric oxygen exposure pressures and oxidative parameters in rat lung, brain, and erythrocytes. Clin Biochem 38:706-711.

59. Zhang Q, Gould LJ (2014) Hyperbaric oxygen reduces matrix metalloproteinases in ischemic wounds through a redoxdependent mechanism. J Invest Dermatol 134:237-246.

60. Mach WJ, Thimmesch AR, Pierce JT, Pierce JD (2011) Consequences of hyperoxia and the toxicity of oxygen in the lung. Nurs Res Pract 2011:260482.

61. Ciarlone GE, Hinojo CM, Stavitzski NM, Dean JB (2019) CNS function and dysfunction during exposure to hyperbaric oxygen in operational and clinical settings. Redox Biol 27:101159.

62. Marcinkowska AB, Mankowska ND, Kot J, Winklewski PJ (2021) Impact of hyperbaric oxygen therapy on cognitive functions: a systematic review. Neuropsychol Rev. doi: 10.1007/s11065-021-09500-9. 